\title{
The Vietnamese Confucian Diplomatic Tradition and the Last Nguyễn Precolonial Envoys' Textual Communication with Li Hongzhang
}

\author{
Gabriel F. Y. TSANG* and Hoang Yen NGUYEN**
}

\begin{abstract}
The Vietnamese envoys' records during their diplomatic journeys to Beijing, especially poems and prose, have attracted increasing academic attention, from both international and local scholars. Some studies have comprehensively examined the Vietnamese envoys' routes when visiting China, literary works, diplomatic strategies, and Confucian beliefs, such as the Taiwanese scholar Chen Yiyuan's (陳益源) journal paper, which specifically problematizes the absence of filial expression related to the envoys' journey in Xiaogan (孝感), Hubei Province. The systematic works of Liam C. Kelley and Peng Qian (彭茜) chiefly delineate the harmonious and normal communication based upon the long-developed cultural congruity between Vietnam and China. Their studies and other relevant research show the sophisticated impact of Chinese Confucianism on the Vietnamese envoys. However, there is so far insufficient investigation into the official representatives' transformation and violation of Confucian manners and thoughts at specific historical moments. Hence, this paper intends to specify the practices of Confucian discourses in the final negotiation between the states of the Nguyễn and the Qing in 1883, both of which encountered the military threat from France and other Western countries. Our findings suggest that although those last envoys, including Phạm Thận Duật and Nguyễn Thuật, utilised a Sinocentric and Confucian manner to bargain with the Chinese for military aid, overall the Nguyễn adopted a Machiavellian approach instead. This means there was a division between political utility and ritual ethics, and the Vietnamese envoys, as pragmatic politicians, prioritized national security while discussing military aid in terms of Confucian rhetoric and values.
\end{abstract}

Keyword: Vietnamese Confucian Diplomatic Tradition, Last Nguyễn Precolonial Envoys, Sinocentrism, Nguyễn Thuật, Phạm Thận Duật, Li Hongzhang

* Gabriel F. Y. TSANG, PhD, Department of Chinese Language and Literature,

Sun Yat-sen University.

Email address: tsangfanyu@hotmail.com

** Hoang Yen NGUYEN, PhD, University of Social Sciences and Humanities, Ho Chi Minh City, VNU-HCM; National Sun Yat-sen University.

Email address: hoangyen@hcmussh.edu.vn

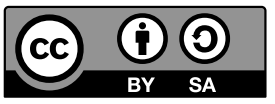




\section{Vietnamska konfucijanska diplomatska tradicija ter dopisovanje med za- dnjimi predkolonialnimi odposlanci vladavine Nguyễn in Li Hongzhangom}

\section{Izvleček}

Mednarodna in domača akademska skupnost čedalje večjo pozornost posvečata zapisom vietnamskih odposlancev, še posebej poeziji in prozi, ki so nastajali med njihovimi diplomatskimi potovanji v Peking. Avtorji so se v posameznih študijah osredotočili na poti, po katerih so potovali vietnamski odposlanci po kitajskem ozemlju, različna literarna dela, diplomatske strategije in konfucijanske ideje. Te še posebej izpostavi tajvanski učenjak Chen Yiyuan (陳益源), ki v svoji razpravi problematizira odsotnost poslušnosti in spoštovanja starejših na potovanju odposlancev v Xiaogan (孝感) v provinci Hubei. Liam C. Kelley in Peng Qiang (彭茜) sistematično prikažeta običajno harmonično komunikacijo, temelječo na kulturni skladnosti med Vietnamom in Kitajsko, ki se je oblikovala v daljšem zgodovinskem obdobju. Tovrstne študije sicer podrobno prikažejo sofisticiran vpliv kitajskega konfucianizma na vietnamske odposlance, a hkrati je še vedno premalo raziskav o uradnih predstavnikih in njihovih transformacijah ter kršenju konfucijanskih načel in idej v specifičnih zgodovinskih trenutkih. Članek zato poskuša prikazati prakse konfucijanskega diskurza $\mathrm{v}$ zadnjih pogajanjih med vladavino Nguyễn in dinastijo Qing leta 1883, ko sta se obe državi soočali z vojaškimi grožnjami Francije in drugih zahodnih dežel. Kljub temu da so zadnji odposlanci, kot na primer Phạm Thận Duật in Nguyễn Thuật, sinocentrična in konfucijanska načela uporabili kot metodo za uspešno pogajanje s kitajsko stranjo za vojaško pomoč, je Nguyễn namesto tega raje prevzel machiavellistični pristop. To kaže na razcep med politično koristjo in ritualno etiko, pri čemer so vietnamski odposlanci kot pragmatični politiki v kontekstu konfucijanske retorike in vrednot pri pogajanjih o vojaški pomoči prednostno obravnavali nacionalno varnost.

Ključne besede: vietnamska konfucijanska diplomatska tradicija, zadnji predkolonialni odposlanci vladavine Nguyễn, sinocentrizem, Nguyễn Thuật, Phạm Thận Duật, Li Hongzhang

The Vietnamese envoys' records during their diplomatic journeys to Beijing, especially poems and prose, have attracted increasing academic attention, from both international and local scholars. There has been scholarship that comprehensively examines the Vietnamese envoys' routes when visiting in China, literary works, diplomatic strategies, and Confucian beliefs, such as the Taiwanese scholar Chen Yiyuan's (陳益源) journal paper Vietnamese Envoys and Xiaogan (Qindai Yuenan shijie yu Xiaogan 清代越南使節與孝感) (2015), which specifically problematizes the absence of filial expression related to the envoys' journey in Xiaogan 孝感, Hubei Province. Other systematic works, such as Liam C. Kelley's monograph Beyond the Bronze Pillars: Envoy Poetry and the Sino-Vietnamese Relationship (2005) and Peng Qian's (彭茜) master's thesis “Tribute 
and Literary Exchange: The Study of Vietnamese Envoys to China in the Qing dynasty and Guangxi" ("Chaogong guanxi yu wenxue jiaoliu: Qingdai Yuenan yu Guangxi yanjiu 朝貢關係與文學交流: 清代越南來華使臣與廣西研究”) (2014) chiefly delineated the harmonious and normal communication based upon the long-developed cultural congruity between Vietnam and China. Their studies and other relevant research show the sophisticated impact of Chinese Confucianism on the Vietnamese envoys. However, there have been insufficient investigations into the official representatives' transformation and violation of Confucian manners and thoughts at specific historical moments.

This paper, based on an illustration of the diplomatic norms of Vietnam in peace, thus intends to specify the superficial practices of Confucian discourses in the final negotiation in 1883 between the states of the Nguyễn and the Qing, both of which encountered the military threat from France and other Western countries. It genealogically clarifies the diplomatic dilemma between subordinating to the sovereign state and prioritizing unethical concerns that especially annoyed the pre-colonial Nguyễn politicians in the late nineteenth century. The following sections of this study will examine the Sinocentrism of Lý Văn Phức's (李文馥) (1785-1849), the most studied Vietnamese envoy, as an introduction to tracing the multifarious sources of Nguyễn diplomatic approaches, and then turn to the written records related to the last Nguyễn precolonial envoys' mission and meeting with Li Hongzhang (李鴻章) (1823-1901), the then diplomatic representative of the Qing government. A contextual investigation of the diplomatic tensions among France, China, and Vietnam will assist in the exploration of individual concerns under the Confucian diplomatic tradition.

\section{Lý Văn Phúcc, and the Confucian Diplomatic Tradition of Vietnam}

Lý Văn Phức argued against Qing local officers who claimed that Vietnam should belong to the civilizational system of China (Hua 華), instead of following the ways of barbarian and backward others ( $Y i$ 夷). As he wrote in Miscellaneous Lyrics of the Fujian Journey (Minxing zayong 閩行雜詠),

In 1831, there was an envoy from Vietnam (Lý Văn Phức himself). He received orders such as escorting lost officers due to typhoon, and hence had to visit Fujian. On 20 August, he arrived at the front door of the official mansion of the provincial capital, and saw a title "The Vietnamese Official Mansion for the Barbarian Envoys" (Yuenan Yishi Gongguan 粵南夷使公館). The mansion was next to the Fujian County office, so the title was given by the County Head Huang Zhaizhong (黃宅中). 
I came, and said "I am not a barbarian, so I would not enter this mansion for barbarians." The accompanying officer cut up the sign, and then we entered. The Head Huang heard this, came immediately, and informed the accompanying officer of his coming. Head Huang is a second-grade imperial scholars. ${ }^{1} \mathrm{He}$ initially did not know this, but then earnestly thanked us and corrected the title to "The Vietnamese Official Mansion for the National Envoys" (Yuenan Guoshiguan Gongguan 粤南國使官 公館). The envoy worried that the people did not have a full understanding, so he wrote “Argument against Yi”" (Bian Yi 讋夷) and showed it in the mansion. (Lý 2010, 257-58)

The title of the mansion reveals two binary and opposing perspectives of identifying Vietnam. Lý Văn Phức complained about Qing officers' mis-recognition of Vietnam as $Y i$, and in his nearly 800-word essay "Argument against Yi" (1831), he attempted to assimilate Vietnam with China through genealogically illustrating its Confucian tradition with the key features of each Chinese dynasty (Lý 2010, 258-62). ${ }^{2}$ In a modern theoretical understanding, he consolidated a hierarchical binary opposition and assigned subaltern Vietnam to the more powerful side. His reverse use of, what Gayatri Chakravorty Spivak (2010, 2115) terms, "epistemic violence", which is originally used to illustrate the West's hegemonic constitution of the colonial subject as Other, validated the authority and superiority of the Vietnamese regime in Southeast Asia. This corresponds to Lý Văn Phức's personal background and the development of the "Small China" concept in Vietnam.

In his journal paper "Between Fujian and Vietnam-Taking the Vietnamese Envoy Lý Văn Phức as an example" (Zai Minnan yu Yuenan zhijian - Yi Yuenan shijie Li Wenfu jiazu wei li 在閩南與越南之間 - 以越南使節李文馥家族為例), Chen Yiyuan derives Lý Văn Phức's Chinese origin from his genealogy. He found

1 The original term is “erjia jinshi” 二甲進士. According to Iona Man-Cheong's summary of the grading of the palace examination for selecting civil servants, the cohort of metropolitan degree holders was divided into three grades. "The top grade (yi jia, also called jinshi jidi; meaning 'ranking presented scholar') contained only three graduates. The second grade (er jia, also called jinshi chushen; 'of presented scholar background') was of no fixed number, and usually contained many more graduates than the first grade but fewer than the third grade (san jia, also tong jinshi chushen; 'equal to presented scholar background'), which contained the highest number of graduates." (Iona 2004, 245)

2 In "Argument against Yi”, Lý Văn Phức wrote about Vietnam: "Using words to manage the legal system is based on two emperors and three kings. Using words to establish traditions is based on six classical works and four philosophical works (of Confucianism). It dwells in Confucius and Mencius, and settles in the Cheng-Zhu school. Its origin of scholarship is The Commentary of Zuo and The Annals of the Warring States, and then Ban Gu and Sima Qian." (Lý 2010, 258-62) And then from the Han dynasty to the Ming dynasty, he listed out Vietnam's compliance with Chinese writing, calligraphy, painting, civil servant examination system, clothing, and so on (ibid.). 
that Lý was a sixth-generation Vietnamese Chinese, whose ancestor Lý Khắc Liêm 李克廉 was Viceroy of Yunnan in the Ming dynasty but, due to the rise of the Qing Empire, turned to serve the Lê dynasty of Vietnam with a hereditary title (Chen 2016, 4-5). Although most of the married wives of the Hanoi Lý family were not Chinese (nor ethnic Chinese settled in Vietnam) (ibid., 6) the family members kept a Confucian tradition, which the high culture Vietnamese governors had long adopted to maintain ethical stability. Their transitional compliance with Vietnam's local Confucianism was welcome and, meanwhile, consolidated the national sense of being a "little China", recognized as superior to the vassal others, and also to the Western nations who arrived later on. As Liam C. Kelly explains, the "little China" theory

argues that during the millennium that Vietnam was part of various Chinese empires (the conventional dating being 111 BC-939 AD), it became a miniature replica of China, and that it was precisely through its contact with the larger kingdom, and by adopting many of its customs and political institutions, that Vietnam was subsequently able to maintain its autonomy for the next thousand years until the advent of French colonization in the nineteenth century. (Kelly 2005, 9)

This theory supposes that the geopolitical connection to an Asian superpower and relevant ritual inertia granted Vietnam specific political authority. Yu Ping 禹平 and Xiao Keyi 肖可意 more concretely illustrate the idea of "little China" in the Qing context. They note that Vietnam had never claimed itself to be "little China", and this concept was first suggested by Korea with the intention to "distinguish Korea, which followed Confucian philosophy and the Chinese ritual system (Hua), from the 'barbarian' (Yi) Qing regime" (Yu and Xiao 2018, 137). For instance, the Vietnamese emperor Minh Mạng (1791-1841) regarded the Qing polity as transforming $\mathrm{Yi}$ into $\mathrm{Hua}$, and its ritual establishment as inferior to Vietnam, the self-identified Southern counterpart of China (ibid., 137-38). ${ }^{3} \mathrm{He}$ implicitly despised Qing's Hua and deemed his Hua a more valid and representative entity that could re-educate the Qing state and subjugate other Southeast Asian states (ibid., 134, 138).

Migrating from China to "little China", Lý Văn Phức's ancestor held an ambiguous cultural belonging to the already collapsed Ming China and to similarly feudal Lê Vietnam. Lý Khắc Liêm preferred Kinh's Hua to the Manchurian Hua.

3 As Yu Ping and Xiao Keyi states, "in the history, Vietnam generally called China the "Northern Dynasty (beichao 北朝])' and itself the 'Southern Dynasty (nanchao 南朝)'” (Yu and Xiao 2018, 137). Vietnam was sharing an ambiguous belonging to China with the China of the sovereign regimes. 
As the descendant of Vietnam's sovereign state, which was later regarded as an inferior political successor of Confucian etiquette, Lý Văn Phức held and advocated a belief in the centrality of Vietnamese Hua, against the peripheral Yi. This imaginatively supported the validity of Vietnamese civilization regardless of the ethnic differences between Chinese, Vietnamese, and Vietnamese Chinese / Chinese Vietnamese. Lý's Sinocentrism beyond personal identity is transnational, but not necessarily trans-dynastic and trans-ethnic. It suggests that Ming's Han rulers and Nguyễn's Kinh rulers inherited the same cultural heritage from the ideally imagined past, whereas Qing's Manchurian rulers failed. Lý only represented the side of Nguyễn's successful inheritance in “Argument against $Y i$ ”, hiding the potential disagreement with Qing civilization.

In 1868, 37 years after Lý Văn Phức wrote "Argument against Yi”, the Vietnamese envoy Nguyễn Tư Giản 阮思僴 read The Atlas of Guangxi (Yuexi diyu tushuo 粵西地輿圖說), published in Guangxi, while visiting Qing China. He found the marking of Vietnam as $Y i$ in it, and hence wrote "On identifying Yi" (Bian Yi shuo 辨夷說) with regard to his hope: “Concerning the word ' $Y i$ ', I hope those who mention it shall promptly make a change, so that fairness can be openly achieved and we can regain a good relationship." (Nguyễn 2010, 234) It was the time after the diplomatic failure of Lý Văn Phức in negotiating with France, the inferior Other in his gaze, had led to the insistence of the Emperors Minh Mạng, Thiệu Trị and Tự Đức on taking measures to protect their Hua culture from French intervention, such as executing control over the growing Catholic communities and imprisoning Western missionaries. However, those measures only accelerated French occupation of Indochina. The political and diplomatic weakness of Vietnam did not undermine its harmonious approach in arguing for its cultural supremacy. The writing of Lý Văn Phức and Nguyễn Tư Giản, as a formal, polite and appropriate approach to conceptually negotiate with the Confucian intellectuals of other states, echoes the Confucian diplomatic tradition of feudal Vietnam that contemporary Vietnamese scholars have described positively.

Trần Ngọc Thêm (2001, 544-22) argues that diplomatic policies are closely related to the core national culture. Hence, the agricultural nature of Vietnam, which formed a collectivist and sentimental lifestyle, would tend to take a friendly approach towards other nations, and to avoid confrontation and wars. Trần Trọng Phiến (2011, 26-27) suggested that the Vietnamese people had been actively developing diplomatic relations with other groups for a long time. In $2357 \mathrm{BC}$ it had the first recorded diplomatic connection with China: the Duke of Zhou 周公 giving the Vietnamese a south-pointing carriage. Then, whenever there was foundation of a new dynasty, the new Vietnamese ruler would initiate a connection with the neighbouring nations, especially China, such as Lý Thái Tổ's 李太祖 
assignment of envoys to the Song court for diplomatic acceptance in 1010 AD, soon after his enthronement.

There was a flexible Confucian way that Vietnamese rulers had long followed to sustain their political and ideological validity. Phan Ngọc (潘玉) (2013) explains that Vietnam regarded itself internally an empire and externally as a kingdom, complying with the hierarchical order of its vassal-sovereign relation with China. Its national spirit was patriotic, independent and autonomous, with an emphasis on ren 仁 and yi 義, denoting a righteous respect even to its military enemies. Towards China, its sovereign state, Vietnam declared and practiced its subordination in response to the Confucian principle that grants the senior an absolute power over the junior. Towards the vassal states of Vietnam, such as Lao and Cambodia, Vietnam used constant conciliation, instead of military intimidation, as the key approach to keeping peace (Phạ 2015, 15; Lê 2015, 33-34). In the view of Đinh Xuân Lâm and Vũ Trường Giang (2014, 3-10), Vietnam shared the same ideological centre as China, regarding the surrounding nations as uncivilized and barbarian, and applied a friendly attitude and strict courtesy to both its sovereign and vassal states. As the details provided by Nguyễn Thị Mỹ Hạnh (2016) show, the Vietnamese rulers of all dynasties were very careful about sending envoys to other nations in order to build and maintain harmonious relations. The selected envoys needed to have passed the civil service examination, with the syllabus based on the Confucian classics, such as the Classic of Poetry and the Analects. ${ }^{4}$ They had to present certain aspects of the Confucian ethos, through creative writing and interpersonal communication, on behalf of the Vietnamese court (Nguyễn 2016, 58).

From the perspective of Vietnamese scholars, even if there were wars, ancient Vietnamese decision-makers would prioritize amity despite the possibility of taking military offense, as Confucianism permits (Yu 2010, 97). ${ }^{5}$ This approach could

4 Doh Chull Shin, To-ch'ol Sin, and To-ch'ŏl Sin (2012) illustrate the spread of Confucianism in ancient Vietnam, during which the civil service examinations, introduced from China, significantly functioned: "After Vietnam became independent from China in 939 AD, the influence of Confucianism grew. As Vietnamese kings and aristocrats struggled to bring order to their unruly kingdom, they embraced the Confucian philosophy emphasizing social harmony and political order. (...) (I)n 1075, civil service examinations in the Confucian classics were introduced. In 1076, the first Vietnamese University was established next to the Temple of Confucius. For the first time in the history of Vietnam, Confucianism began to share a place at the royal court with Buddhism." (Shin, Sin and Sin 2018, 35)

5 Yu Kam-por's journal paper "Confucian Views on War as Seen in the Gongyang Commentary on the Spring and Autumn Annals" suggests that Confucianism "sheds light on war against enemies of civilization, conditions for waging a preemptive war, punitive expedition, as well as the use of weapons of mass destruction." It summarized Confucian understanding of war as realistic, pragmatic, but humanistic (Yu 2010, 97). 
maintain peace between states, and meanwhile minimize the casualties of both sides and the disturbance to the public. Trần Trọng Kim (2018) notes that, in 982, the Lê army defeated the Song army, but soon initiated reconciliation with the Song court. Besides, in 1479, the Lao army harassed the Vietnamese at the border between Lao and Vietnam. Lê sent some troops and chased the Lao army back to the border of Myanmar. Despite winning an absolute victory, the Lê army did not take that chance to occupy Lao, but instead retreated in order to repair the relationship with Lao (Trần 2018, 272). Moreover, Trần Trọng Phiến (2011) argues that, no matter whether in the wars for independence or for protecting national sovereignty, the Vietnamese rulers would focus on expelling the enemies from their land, rather than killing them. For example, in 1077, after the Lý army defeated the Song army, the general Lý Thường Kiệt (李常傑) did not insist on annihilating them. Instead he chose to use diplomatic methods to persuade them to unarm (ibid., 28).

In the views of contemporary Vietnamese scholars, Vietnamese diplomacy was Confucian at this time in the sense that it submissively guaranteed the structural stability of the hierarchical power orders of Asia, with a ritual appropriation of communication and a humanitarian concern about civilian life. However, such views only reflect the optimistic and ideal aspects of Confucian practices. As many scholars have noted, Confucianism is too rigid to mediate between inner desire and formal etiquette. For instance, Wu Sen (吳森) complains that over-ritualization in the Confucian culture had repressed genuine expression of feeling and led to insincere communication (Wu 1995, 55-98). Therefore, both the historical records and scholarly discourse that arose under the influence of Confucianism might not show the potential duality of political decisions. The discursive rhetoric used to safeguard the individual and collective dignity would overshadow the pragmatic concerns and methods that conflict with Confucian discipline.

Another issue that deserves attention is the interior compatibility and practical constraints of Confucian philosophy. As Li Chenyang asks, "If Confucianism promotes both harmony and ritual propriety, how does it bring them in tune?" (Li 2013, 128). He answers that classic Confucians had flexibility to resolve the incompatibilities between maintaining ritual correctness and sustaining peaceful situations through stressing the idea of "weighting". ${ }^{6}$ However, although it

6 Li Chenyang illustrated that "One way to see such flexibility is to examine the notion of quan (權), or discretional action. The word originally means a weighing instrument (cheng 秤) or the weight used in such an instrument (cheng tuo 秤釷). By extension, it also means the act of weighing. From this sense of weighing comes the meaning of quan as discretion. Quan as discretional action is a skill of making appropriate decisions with considered flexibility to suit specific situations. As such, it means situational decisions with discretion. The notion of quan is important in Confu- 
is correct, as Li would agree, that discretional action can flexibly apply general Confucian rules in specific situations for the best outcome, the practical needs (or at least temptations) of taking contingency plans out of Confucian acceptance should not be underestimated. Moreover, the idea of weighting could encounter challenges when applied in actual political dilemmas. Self-established as an orthodox Confucian regime, the Nguyễn court regarded the rulers of both Qing and France as barbarians. It did not share the same high-cultural value system as the Qing dynasty, the failed successor of Confucianism, or the French, the uncivilized invaders. In the final negotiation between the Nguyễn and Qing to safeguard the autonomy of Vietnam from the French military actions, Nguyễn officers did not show a belief in the Qing court's willingness to fulfil Confucian requirements, such as protecting vassal states. Simultaneously, they were not faithful to their sovereign state, keeping their national plight a secret until the country needed Qing aid. The following sections will first provide some details about the last Nguyễn envoys' visits to Tianjin before the French colonization of Vietnam, and then connect the patriotic personal statement of a representative envoy, Nguyễn Thuật (阮述) (1842-1911), to the textual communication ${ }^{7}$ with a Confucian attitude between the Vietnamese envoys and Li Hongzhang. There is thus the intention to explore the practical discordance between the ideal Confucian diplomatic tradition and the pragmatic use of Confucian rhetoric for certain political purposes.

\section{The Final Diplomatic Trip of Nguyễn Envoys to China}

The Annals No. 4 Vol. 68 of The Principal Veritable Records of the Great South (Đại Nam Thưc Luc Chinh Biên 大南定錄正編) documented that, in December 1882, the last precolonial emperor Tự Đức 嗣德 (1829-1883)

assigned Phạm Thận Duật 范慎逼 (1825-1885), the Minister of Justice (Xingbu Shangshu 刑部尚書), as Imperial Envoy (Qinchai Dachen 欽差 大臣) and Nguyễn Thuật, the Deputy Minister with the title of Assistant

cian philosophy. Mencius said, for instance, 'quan first, then one knows the light and the heavy; measure first, then one knows the long and the short' (Mencius 1A7; TTC 2670-1). For matters of importance, we should 'weigh' the situation before action and then act accordingly. In Confucian texts, this word implies maintaining a flexible attitude toward existing rules in performing particular actions." (Li 2013, 128)

7 Liu Yujun 劉玉珺 stated that “Han text is only the official written language of Vietnam. It cannot penetrate daily communication. Therefore, Vietnamese intellectuals all know Han text, but most of them could not use Han language to directly exchange ideas. They can only communicate through textual chats." (Liu 2007, 362) 
Administrator (Shilang jia Can Zhi Xian 侍郎加參知銜), as Deputy Imperial Envoy (Fushi 副使), sending them to Tianjin of the Qing Empire for an official mission. (Xu and Xie 2000, 459)

This was a response to the request of Li Hongzhang, the then Northern Commissioner of Trade (Beiyang dachen 北洋大臣) ${ }^{8}$ to consult two to three Nguyễn officers about affairs between Vietnam and France. After signing the Treaty of Saigon (1862) and the Second Treaty of Saigon $(1874)^{9}$ with France, the Nguyễn government had lost its sovereignty over Cochinchina. On the Qing side, Li Hongzhang would hope to prepare for Chinese-French-Vietnamese tripartite talks with Albert Bourée (the French ambassador in China from 1880 to 1883), in which the Vietnamese envoys might act as an information provider (Wang 2013, 67). ${ }^{10}$ On the Nguyễn side, the two envoys expected the Qing government to mediate between France and Vietnam, ${ }^{11}$ and to offer naval aid for their coastal defence against the French military. ${ }^{12}$ As Nguyễn Thuật recorded in A Diary of Visiting Tianjin (Wang Jin riji 往津日記), which noted his thoughts on setting out for Hong Kong and Guangdong with Lê Đăng Trinh (黎登貞), Nguyễn Tịch (阮藉), and Đỗ Phú Túc (杜富肅), and the Qing officers Tang Jingsong (唐景崧) and Ma Fuyu (馬復賁) on 16 January 1883 (Nguyễn 1980,19) to arriving at the Hòa Khiêm Hall (和謙殿) on 26 January 1884 (ibid., 64), the final hope of

8 There were two superintendents of trade under the Foreign Affairs Office (Zongli Yamen 總理 衙門), the official organization (set up in 1861) in charge of all the foreign issues of the Qing Empire: one for the Northern Ports as Northern Commissioner of Trade and the other for the Southern Ports as Southern Commissioner of Trade. They both "shared the responsibility over foreign and trade affairs of the northern and southern coastal areas." (Li 2018, 144) The Northern one, held by Li Hongzhang from 1870 to 1901, overpowered the Southern one, intervening in the Vietnamese affairs.

9 John Kleinen summarizes that the Second Treaty of Saigon was a revision of the first one. "This time the Court had to cede the whole of Cochinchina in the South to the French, opening the Red River to commerce and allowing the French to open consulates in Hanoi, Ninh Hai (near present day Haiphong) and Thi Nai (in the central province of Binh Dinh)." (Brocheux and Hemery in Kleinen 1999, 47)

10 Wang argued that Li Hongzhang flexibly turned the role of Vietnam as "participating in the negotiation" to "auditing for consultation", so that France would accept the presence of Vietnamese delegates in the talk (Wang 2013, 67).

11 Nguyễn Thuật wrote during his Tianjin visit, "The Chinese court originally sent a document to assure its willingness to mediate for the affairs between my nation and France.” (Nguyễn 1980, 49) It turned out a disappointment as Nguyễn blamed that the Qing state could not fulfill the responsibility of protecting his vassal state.

12 As recorded in On Sino-French Vietnamese Negotiations 1875-1911 (Zhong Fa Yuenan jiaoshe Dang 1875-1911 中法越南交涉檔 1875-1911), Phạm Thận Duật told Li Hongzhang, as an implicit request, "Only if the heavenly court (pointing to the Qing court) could send out battleships to help defend the pass, there could be no obstacles" (Guo 1962, 716). 
a nearly re-colonialized state failed due to Li Hongzhang's ambiguous attitude. The interior weakness of China after the two Opium Wars (1839-1842; 1856$1860)$ and the Taiping Rebellion (1850-1864) led to Li's discreet maintenance of a sovereign-vassal connection. His tardiness in dealing with the sovereignty of Vietnam finally triggered France's prompt military occupation of Huế, the capital of the Nguyễn dynasty from 1802 to 1945 (Zhang 2002, 534). The French victory, upon the death of Emperor Tự Đức on 19 July 1883, compelled the Vietnamese government to sign the Treaty of Huế on 25 August 1883, which recognized the French protectorate over Annam and Tonkin. On 4 September 1883, the Vietnamese envoys had the second and also the last meeting with $\mathrm{Li}$ Hongzhang, explaining their especially difficult situation concerning the newly signed treaty (Nguyễn 1980, 50). On 12 November 1883, Li Hongzhang finally approved the Vietnamese envoys' request to return to Vietnam, and ended their failed mission (ibid., 56). This marked a disconnection between two culturally Confucian entities.

From the beginning to the end of the Tianjin journey, despite its failure, the Vietnamese envoys maintained a Sinocentric and Confucian manner to bargain with the diplomatic representative of their most superior monarch. To a certain extent, they adopted a Machiavellian approach, here signifying a methodological division between political utility and ritual ethics, the former of which was given highest priority. There is no intention to justify the reception and potential influence of Machiavellian thoughts in Nguyễn Vietnam, but merely to capture a corresponding key feature for elaboration instead. As Steven Forde summarizes,

Machiavelli develops the realist argument in its purest form, arguing that the nature of international politics absolves states of any moral duties whatsoever. He endorses imperialism, the unprovoked subjugation of weaker nations by stronger without reservation and without limit. $\mathrm{He}$ develops a new and amoral basis for the political community, to conform with the necessities of international politics as he sees them, and to reflect his negative assessment of the status of moral principle altogether. (Forde 1992, 64)

Vietnam was a vassal state, only imperialistic to its sub-vassal states, such as Lao, Cambodia, Thủy Xá and Hỏa Xá. However, toward its sovereign state it would also apply the Machiavellian mindset to bargain for maximal benefits, rather than absolutely obeying the "monarch", as Confucian hierarchical ethics advocates. In the realm of international politics, rigid compliance with the rites and commands of the superior might restrict national authority. Hence, amorality with greater flexibility to make decisions is more preferable than ideological correctness. As 
a real case, despite not necessarily disregarding morality, the Vietnamese envoys, as pragmatic politicians, would prioritize national security while utilizing Confucian rhetoric and values to negotiate with Li Hongzhang. Their twofold representation of political intention and discursive appropriation deserves much attention, as it reveals that the diplomatic tradition of a vassal state is not a homogeneously obedient unity in the context of global colonization. The cultural inertia originated from an ambiguous geographical understanding of $\mathrm{Hua}$, a then currently disintegrating superpower, was simultaneously forming ideological sublimation and political dissidence.

\section{Nguyễn Thuật, Phạm Thận Duật and the Textual Negotiation with Li Hongzhang}

As one of the core Vietnamese representatives, Nguyễn Thuật expressed his deep patriotism and sentimental attachment to Vietnam through poetry. In his collection of poems Whenever Missing and Chanting the Grass (Meihuai yincao 每懷 吟草), there are verses written during his first journey to China, such as "Calculating the date of return / Desiring to exhaustively reward my nation in turn" and "Not tired of lingering for mornings and dusks / The leaving yachts long carried tomorrow's missing" (Hồ 2017, 103). ${ }^{13}$ He utilized a literary form originating from Hua China to deliver proper utterances that suited his identity as an envoy. Examining his views shown in poems can reveal his perceptions of Vietnam-China relations and provide a reference to his later compliance with a "barbarian" regime.

In a nationalist sense, Nguyễn Thuật understood that Vietnam shared the same source and sustenance of civilization as the geographically identified China, but implicitly differentiated Qing China from the China of Han regimes. He knew that his visit required proper neighbourhood etiquette, so he "hope(d) to emphasize the Han official rite" (ibid., 107-8). ${ }^{14}$ As a key word usually used to signify

13 Two verses were quoted from the poems "Granted another annually promoted position as Assistant Minister of Rites and Envoy in 1881 (Xinsi sui gong meng gaishou Li Bu Zuoshilang chong Zhengshi 辛巳歲貢蒙改授禮部左侍郎充正使)" and “Recently following a royal commend to create four poems with gonghe rhyme and the same rhyme that thanks Assistant Provincial Head of Ningming Luo Jinchi (Jinxing feng yuzhi si shi gonghe yuan yun ciyun chou Ningming Zhizhou Luo Jinchi 近行奉御制四詩恭和原韻 次韻酬寧明知州羅晉池)”, respectively.

14 Quoted from the poem "Answering to the five-word poem granted by Du Ciqing from the Ministry of Rites who walked me to the end of Royal River in the set-off day (Qixing ri Li Bu Du Ciqing songzhi Yu He kou zhan wuyan yi zeng, fu ci fengda 啟行日禮部杜次卿送至禦河口佔五言 以贈, 夫此奉答)". 
China, also in the verses such as "Thereafter, lyingly travelling across Han river islets thoroughly", (ibid., 128-29) ${ }^{15}$ Han could have two meanings, related to the previously prosperous Han dynasty (202 BC-220 AD) and the Han people. This was a long overthrown regime and not a ruling class in Nguyễn Thuật's era. However, he, in the poems responding to other officers, accented Vietnam's pre-Qing inheritance of Han civilization: "The South of Yunnan (Vietnam) long using the same standards for roads and words" and "Situated as the same archived states" (ibid., 134-38). ${ }^{16}$ The far-reaching imagination of the regressionist ideal of Han was ambiguously denying the Qing Manchurian regime, which he regarded as failing to take its responsibility to save Vietnam, the culturally, but not ethnically nor geographically, valid descendant of Han.

As an officer who later served the Nguyễn puppet government under French control until his death in 1911, Nguyễn Thuật's Confucian manner could not be as straightforward as Lý Văn Phức presented. In Lý's era, national power enabled the government, despite being subordinated to the Qing, to repress and expel the Westerners, whose nations were not authorized as valid by Confucian ceremonies. ${ }^{17}$ However, due to the weakening diplomatic power of Vietnam, Nguyễn Thuật had to make concessions in response to the changing international dynamics, accepting the absolute reign of an uncivilized and barbarian power.

From the precolonial Vietnamese envoys' final voyage to China, there can be found the ambivalent attitude of Vietnamese politicians to experiencing the inefficiency of Confucianism with regard to sustaining the long established hierarchical order of Far East powers. On the one hand, they could only privately complain about the Qing's reluctance to righteously protect its vassal state. On the other hand, they had to publicly communicate with Qing officers with courtesy. In $A$ Diary of Visiting Tianjin (1980), ${ }^{18}$ Nguyễn Thuật wrote on 31 August 1883 after

15 Quoted from the poem “In a boat of Ming River (Ming Jiang chuan zhong 明江船中)”.

16 Quoted from the poems "Same Rhyme for Thanking Central Secretary Zhang Tangyin (Ciyun chou Zhongshu Zhang Tangyin 次韻酬中書張棠蔭)", and "Same Rhyme for Thanking Li Bichang (Ciyun chou Li Bichang 次韻酬李必昌)”, respectively. As Yu Ping and Xiao Keyi (2018, 134) found, the Nguyễn court would regard an archived state, which could succeed Han cultural traditions, such as Korea, as superior to other states, such as Thailand.

17 Both Đinh Dung (1997, 73-78) and Phạm Thị Lan (2017, 104-9) recognize this kind of authorization as a key Confucian tradition that Vietnam adopted to value itself and other nations. An unauthorized condition is the reason why Vietnam diplomatically refused to communicate with the Western Yi countries.

18 As Wang Zhiqiang differentiates, A Diary of Visiting Tianjin is a private record of the Tianjin journey, unlike The Daily Record of the Qing Journey in Kiến Phúc First Year (Jianfu Yuannian Ru Qing Richeng 建福元年如清日程), which is an official record of the same journey that Nguyễn Thuật and Phạm Thận Duật cowrote for the Vietnamese emperor (Wang 2013, 57). 
learning of Emperor Tự Đức's death and the fall of cửa Thuận An (順安汛) under French attack:

We are all furious. The Chinese court originally sent a document to assure its willingness to mediate for the affairs between my nation and France. They call us to Tianjin for consultation, but have not yet held a talk, and also worry and hesitate about assisting us with battleships. As a result, France forced us to surrender while there was an incident. My nation is at the convergence of many changes and problems. It cannot but obey. How can the Chinese court that cannot protect its vessel states explain itself eloquently to the world? (Nguyễn 1980, 49)

Nguyễn Thuật explicitly expressed his discontent with the Qing court, which was not loyal to the Confucian ethical regulations. In fact, as recorded in $O n$ Sino-French Vietnamese Negotiations 1875-1911 (Zhong Fa Yuenan jiaoshe dang 1875-1911 中法越南交涉檔 1875-1911), Li Hongzhang was personally conscious of the military limitations of China: "The Southern and Northern navy has not been trained up yet, and hence definitely cannot be sent far away. Moreover, France is good at naval battles, which Chinese battleships could not win actually" (Guo and Wang 1962, 713). He prioritized the probability of victory and the ability of the Qing government to pay, instead of traditional obligation. However, despite failure in achieving consensus, both the Vietnamese envoys and Li Hongzhang held a friendly attitude towards each other in their recorded communication.

In their first and most significant meeting, Li Hongzhang first asked about the physical conditions of Phạm Thận Duật and his "king":

Li: Have you recovered?

Phạm: Your subordinate has luckily $70 \%$ recovered from the poor disease.

Li: How is your king? There was a document that mentioned his sickness. What kind of sickness is it?

Phạm: Depending on the good fortune of the heavenly court, the king of the subordinate nation is good. However, as many incidents happened in recent years, worries caused his illness, such as coughing and feeling dizzy. (Guo and Wang 1962, 713-14)

This kind of warm-up conversation properly delivered intimacy and minimized any utilitarian perception. It also foregrounded the power-relation between China 
and Vietnam, because Li, instead of Phạm, initiated a consolation and Phạm could only answer with emphasis on the inferior position of himself and his nation.

Then they discussed two main issues: Vietnam's secret signing of treaties with France and its naval defence against France's further invasion. Concerning the first issue, Li Hongzhang first asked how many treaties Vietnam had signed and when they were signed. After Phạm Thận Duật answered that the first treaty was signed in 1862 and a renewal signed in 1874, Li stated:

The treaties between vassal states and other states, such as those of Korea and Japan, must be reported to the heavenly court. The original text of the treaties shall be submitted to the Ministry of Rites ( $L i b u$ 禮部) for passing. Now all the treaties with America, Britain, and Germany have to be approved by the Chinese court. I, as a senior officer, would send staff to the conferences, so that the conditions of the treaties would be only beneficial and not disadvantageous. Your nation signed the treaties with France without permission, not clarifying this issue for the heavenly court but later sending delegates to report it. This apparently violates the regulation of vassal states. Ten years had passed. What is the use of now submitting the manuscript of the treaties? (Guo and Wang 1962, 714)

Li, as the representative of the sovereign state, blamed the Nguyễn court for late notification. He managed the proper diplomatic procedure of resolving international risks, and controlled the power of negotiating with the Western powers on behalf of the vassal states. In response, Pham could only politely apologize for the mistake, which was based on the Nguyễn's doubts about the Qing's military strength after two Opium Wars, in order to bargain for naval support:

In those years, France was powerful and hence bullied your subordinate state. We urgently sought for peace and did not understand the rules for this new kind of incident, so we had such a violation. There is no way to get rid of our crime, but a hope that the heavenly court might understand the urgent situations, hence forgive our mistakes and emphasize our later goodness. If your subordinate state can be long blessed by your protection. It is the good fortune of your subordinate state. (ibid.)

Beyond the outcome of the negotiation (Li's implicit rejection of offering diplomatic and defensive aids) and the factual development of Vietnamese-Chinese-French relations, which many historians have examined in depth, the manner applied in the process reveals a different kind of tension. Phạm meticulously 
set out the ignorance, reluctance, and guilt of Vietnam, repeatedly pleasing Qing's officers through stressing the superiority of the Qing and the inferiority of the Nguyễn with binary-opposite identification, such as "heavenly court" (tianchao 天朝) and "subordinate state" (xiaguo 下國). This corresponds to the discourse of his Emperor, who repeatedly mentioned how the Qing court had protected Korea, a vassal state like Vietnam, against Japan and the West, and intentionally used words like “sympathize” (恤及), “protect (subordinate state)” (柔遠), “perceive morality/virtue" (感德), “benevolence” (恩德), “understand with forgiveness" (諒解), “great state” (大國), “vassal state” (藩屬國), “long looking-up” (久仰 之情), etc. The subordinated imperial speech held hope of recalling the legitimate responsibility of the Qing regime to protect Vietnam as a truly superior court, according to the Confucian moral hierarchy. ${ }^{19}$ In such a rhetorical context, the Qing representative with absolute authority was supposed to bestow good fortune on the poor Nguyễn through practical actions. However, the discussion ended up with Li Hongzhang claiming, "We can now only follow France, as the French do not want to discuss Vietnamese affairs with China" (Guo and Wang 1962, 717). Pham could only choose between discussing the matter with Li again, after Li's time away for a funeral, returning to Vietnam, or talking to Zhang Gongbao 張宮保, who was Li’s delegate.

\section{Conclusion}

The Vietnamese envoy's proper but implicit reminder of Confucian norms did not result in any substantial achievements and promises. The reason is not simply that Li could find a counterargument to imply that Vietnam's prior violation of the norms led to the Qing not fulfilling its responsibility. More significantly, the habitual use of Confucian ethical discourse could not effectively change the stance of $\mathrm{Li}$, who merely sought information, not opinions. Li aimed to maximize the benefits of the Qing, just as the Nguyễn court did during the French military intimidation. Both sides disregarded the Confucian requirement of faithfulness and righteousness but demanded that the other comply with it. Therefore, the determinate factor of this kind of negotiation between the sovereign state and vassal state, and even of the politics of the entire Far East Confucian cultural sphere, is the power relation that prioritized national interests from the centre to the peripheries, not morality. Confucianism malfunctioned, except as a degrading prerequisite for maintaining political validity. As a subordinate regime and a

19 Refer to the letter that the Nguyễn Emperor wrote to the Qing Emperor recorded in On Sino-French Vietnamese Negotiations 1875-1911 (Guo and Wang 1962, 710). 
self-recognized Confucian successor, the House of Nguyễn could only passively safeguard its ritual dignity, which gave no significant help to its political and diplomatic plight, until its end in 1945.

\section{References}

Chen, Yiyuan 陳益源. 2015. “Qingdai Yuenan shijie yu Xiaogan 清代越南使 節與孝感 (Vietnamese Envoys and Xiaogan ).” Journal of National Cheng Kung University 50: 85-108.

. 2016. "Zai Minnan yu Yuenan zhijian - Yi Yuenan shijie Li Wenfu Jiazu wei li 在閩南與越南之間 - 以越南使節李文馥家族為例 (Between Fujian and Vietnam-Taking the Vietnamese Envoy Lý Văn Phứ as an Example).” Journal of Applied Chinese 17: 1-16.

Đinh, Dung. 1997. "Thử tìm hiểu ảnh hưởng của Nho giáo trong đường lối ngoại giao của triều Nguyễn nửa đầu thế kỷ XIX (Confucianism Influence on the Nguyễn Dynasty's Foreign Policy during the First Half of the XIX Century)." Research on History (295): 73-78.

Đinh, Xuân Lâm, and Vũ Trường Giang. 2014. "Tìm hiểu một số đặc điểm của ngoại giao Việt Nam thời phong kiến (On Some Characteristics of Vietnamese Foreign Policy during Feudal Period)." Southeast Asia Studies (67): 3-10.

Forde, Steven. 1992. "Classical Realism." In Traditions of International Ethics, edited by Terry Nardin, and David R. Mapel, 62-84. Cambridge: Cambridge University Press.

Guo, Tingyi 郭廷以, and Wang Yujun 王聿均. 1962. Zhong Fa Yuenan jiaoshe dang 1875-1911 中法越南交涉檔 1875-1911 (On Sino-French Vietnamese Negotiations 1875-1911). Taipei: The Institute of Modern History Academia Sinica.

Hồ, Ngọc Minh. 2017. "Nghiên cứu và phiên dịch tác phẩm Mỗi hoài ngâm thảo 每懷吟草 của Hà Đình Nguyễn Thuật (Research and Translation of Hà Đình Nguyễn Thuật's Mỗi hoài ngâm thảo 每懷吟草).” MA thesis, Hochiminh City University of Social Sciences and Humanities.

Iona, Man-Cheong. 2004. The Class of 1761: Examinations, State, and Elites in Eighteenth-Century China. Palo Alto: Stanford University Press.

Kelley, Liam C. 2005. Beyond the Bronze Pillars: Envoy Poetry and the Sino-Vietnamese Relationship. Honolulu: The University of Hawai'i Press.

Kleinen, John. 1999. Facing the Future, Reviving the Past: A Study of Social Change in a Northern Vietnamese Village. Singapore: Institute of Southeast Asian Studies. 
Lê, Thị Lan. 2015. “Tư tưởng trị quốc của Gia Long (The Ideology of Governing the Country of Emperor Gia Long)." Tạp chi Khoa họ xã hội Việt Nam (Vietnamese Journal of Social Sciences) 12: 33-40.

Li, Chenyang. 2013. The Confucian Philosophy of Harmony. Abingdon: Taylor and Francis.

Li, Xue. 2018. Making Local China: A Case Study of Yangzhou, 1853-1928. Münster: LIT Verlag.

Liu, Yujun 劉玉珺. 2007. Yuenan Han Nan guji de wenxianxue yanjiu 越南漢 喃古籍的文獻學研究 (A Philological Study of the Hán Nôm Records). Beijing: Chunghwa Book.

Lý, Văn Phức 李文馥. 2010. “Minxing zayong 閩行雜詠 (Miscellaneous Lyrics of the Fujian Journey)." In Yuenan Hanwen Yanxing wenxian jicheng (Yuenansuo cangbian) Di 12 ce 越南漢文燕行文獻集成 (越南所藏編) 第12冊 (Full Collection of Vietnamese Yanxing Literature (The Vietnam Edition, vol. 12), edited by The Literature and History Research Institute of Fudan University and The Vietnamese Institute of Hán Nôm. Shanghai: Fudan University Press.

Nguyễn, Thị Mỹ Hạnh. 2016. "Nho giáo trong nền ngoại giao Việt Nam thời trung đại (Confucianism and the Vietnamese Foreign Policy during Feudal Period)." Khoa học xã hội Việt Nam (Vietnamese Journal of Social Sciences) 12: 55-62.

Nguyễn, Thuật 阮述. 1980. Wang Jin riji 往津日記 (A Diary of Visiting Tianjin). Hong Kong: Chinese University of Hong Kong Press.

Nguyễn, Tư Giản 阮思僴. 2010. “Yanyao shiwen ji 燕軺詩文集 (The Collection of Essays and Poems of Yanyao)." In Yuenan Hanwen Yanxing wenxian jicheng (Yuenansuo cangbian) Di 20 ce 越南漢文燕行文獻集成 (越南所藏 編) 第20冊 (Full Collection of Vietnamese Yanxing literature, The Vietnam Edition, vol. 20), edited by The Literature and History Research Institute of Fudan University and The Vietnamese Institute of Hán Nôm. Shanghai: Fudan University Press.

Peng, Qian 彭茜. 2014. “Chaogong guanxi yu wenxue jiaoliu: Qingdai Yuenan lai Hua shichen yu Guangxi yanjiu 朝貢關係與文學交流: 清代越南來華 使臣與廣西研究 (Tribute and Literary Exchange: The Study of Vietnamese Envoys to China in the Qing Dynasty and Guangxi)." MA thesis, Guangxi University for Nationalities.

Phạm, Thanh Hằng. 2015. “Ảnh hưởng của Nho giáo đến kế sách ngoại giao, quân sự thời phong kiến và ý nghĩa đối với hiện nay (The Impact of Confucianism on Foreign and Military Policy during Feudal Period and its Contemporary Meanings)." Tạp chí Lý luận chính trị (Journal of Political Theory) 8: 13-19. 
Phạm, Thị Lan. 2017. "Vai trò xã hội của Nho giáo Việt Nam từ thế kỷ XV đến nửa đầu thế kỷ XIX (The Social Value of Vietnamese Confucianism from the XV to the First Half of the XIX Century)." PhD diss., Institute of Social Sciences, Hanoi.

Phan, Ngọc. 2013. "Nền tảng của truyền thống ngoại giao Việt Nam (The Foundation of Vietnamese Foreign Policy Tradition)." Tạp chí điện tử Văn hiến Việt Nam (Online Vietnam Culture Journal), September 25, 2013.

Shin, Doh Chull, To-ch'ol Sin, and To-ch`ŏl Sin. 2012. Confucianism and Democratization in East Asia. Cambridge: Cambridge University Press.

Spivak, Gayatri Chakravorty. 2010. "From A Critique of Postcolonial Reason, chap. 3: History (Can the Subaltern Speak?)" In The Norton Anthology of Theory and Criticism, edited by Vincent B. Leitch et al. New York: W. W. Norton \& Company.

Trần, Ngọc Thêm. 2001. Cơ sở văn hóa Việt Nam (Outlines of Vietnamese Cultural Foundation). Hà Nội: Education Publishing House.

Trần, Trọng Kim. 2018. Việt Nam sử lược (A Brief History of Vietnam). Hà Nội: Literature Pulishing House.

Trần, Trọng Phiến. 2011. "Văn hóa đối ngoại Việt Nam thời Minh Mạng (Vietnamese Foreign Policy Culture during Minh Mang).” MA thesis, Ho Chi Minh City University of Social Sciences and Humanities.

Wang, Zhiqiang 王志強. 2012. "Yuenan Hanji Ruanshu Wang Jin riji yu Jianfu yuannian ru Qing richeng de bijiao 越南漢籍《阮述〈往津日記〉》與 《建福元年如清日程》的比較 (A Comparaison between the Vietnamese Chinese Records Nguyễn Thuật's A Diary of Visiting Tianjin and The Daily Record of the Qing Journey in Kiến Phúc First Year)." Around Southeast Asia 12: 56-59.

. 2013. "Li Hongzhang yu Qingdai zuihou de Yuenan lai Huan shijie 李 鴻章與清代最後的越南來華使節 (Li Hongzhang and the Last Vietnamese Envoy to China in the Qing Dynasty)." Lantai World 28 (3): 67-68.

Wu, Sen 吳森. 1995. “Qing yu Zhongguo wenhua 情與中國文化 (Love and Chinese Culture).” In Zhongguo wenhua zhuanti 中國文化專題 (The Selected Topics of Chinese Culture), edited by Lin Qiyan 林啟彥, and Huang Yanli 黃 嫣梨. Hong Kong: Hong Kong Educational Publishing Company.

$\mathrm{Xu}$, Wentang 許文堂, and Xie Qiyi 謝奇懿, eds. 2000. Đai Nam Thu Cluc Chinh Biên 大南定錄正編 (The Principal Veritable Records of the Great South). Taipei: Taiwan Academia Sinica Southeast Asia Regional Research Program.

Yu, Kam-por. 2010. "Confucian Views on War as Seen in the Gongyang Commentary on the Spring and Autumn Annals." Dao 9 (1): 97-111. 
Yu, Ping 禹平, and Xiao Keyi 肖可意. 2018. “Qing Yue chaogong liyi zhi zheng de sixiang genyuan 清越朝貢禮儀之爭的思想根源 (The Mind Source of the Disputes between Qing and Vietnam Concerning the Tribute Ritual)." Social Science Front 1: 133-40.

Zhang, Zhenkun 張振鶡, ed. 2002. Zhongguo jindai shi ziliao congkan xubian - Zhong Fa zhanzheng (Di si ce) 中國近代史資料叢刊續編 - 中法戰爭 (第四冊) (The Edited Data Series of Chinese Modern History-Sino-French War (vol. 4)). Beijing: Zhonghua Book. 